\title{
Metabolic and endocrine changes induced by chronic heat exposure in broiler chickens: growth performance, body composition and energy retention
}

\author{
BY P. A. GERAERT, J. C. F. PADILHA* AND S. GUILLAUMIN \\ Station de Recherches Avicoles, Institut National de la Recherche Agronomique, \\ 37380 Nouzilly, France
}

(Received 1 December 1994 - Revised 27 April 1995 - Accepted 18 May 1995)

\begin{abstract}
The present study was performed in order to investigate the effect of chronic heat exposure (32 ${ }^{\circ}$, constant) on growth, body composition and energy retention of broiler chickens in relation to age. At 2 and 4 weeks of age, fifty-four male Shaver broiler chickens were allocated to three treatments according to the following design: $22^{\circ}$, ad lib. feeding (22AL); $32^{\circ}$, ad lib. feeding (32AL); and $22^{\circ}$, pair-feeding with the $32^{\circ}$ group (22PF). Ambient temperature was kept constant at either 22 or $32^{\circ}$ for 2 weeks. Heat exposure decreased feed intake by $14 \%$ between 2 and 4 weeks and by $24 \%$ between 4 and 6 weeks of age. Even with the same feed intake, chicks gained less weight at $32^{\circ}$ than at $22^{\circ}, 5.5 \%$ less in young chickens and $22 \%$ less in older ones. Hot environmental conditions thus resulted in decreased feed efficiency; the feed:gain ratio was 2.85 at $32^{\circ}$ compared with 2.06 at $22^{\circ}$ in $22 \mathrm{AL}$ birds for the period 4-6 weeks. Body composition appeared significantly affected by high ambient temperature. Feathering was reduced at $32^{\circ}$ in absolute weight but not as a proportion of body weight. Heat-exposed birds showed a decrease in body protein content, protein gain and protein retention. Group 32AL birds were fatter than the pair-fed (22PF) or ad lib.-fed (22AL) groups at $22^{\circ}$. The percentage of energy retained as fat was 79 in heat-exposed chickens compared with 64 in the control groups. The energy retained as protein:energy retained as fat for groups maintained at $22^{\circ}(0.56)$ was twice that for those maintained at $32^{\circ}(0 \cdot 28)$. These modifications should be investigated further in relation to metabolic and endocrinological changes.
\end{abstract}

Chronic heat exposure: Growth: Body composition: Energy retention

Chronic heat exposure and heat stress are causing increasing concern to poultry production in hot climates as well as in temperate countries due to reduced growth performance and increased mortality. Birds, like mammals, are homeotherms, thus they are able to maintain a near-constant body temperature. To achieve a constant body temperature, heat produced by metabolism must equal heat loss. In birds, heat losses are limited by feathering and by the absence of sweat glands. The main consequence of heat exposure is a reduction in feed intake in order to reduce metabolic heat production. This reduction is approximately $17 \%$ per $10^{\circ}$ increase in ambient temperature above $20^{\circ}$ (Austic, 1985). This decreased feed intake leads to growth depression. However, the reduction in growth is often greater than the reduction in feed intake, resulting in a lower feed efficiency (Howlider \& Rose, 1987). Hot conditions appear to have a direct effect on growth which is independent of the effect on feed intake (Aï Baziz et al. 1990).

From a nutritional point of view, this reduction in growth for a given feed intake has yet to be explained. Indeed, the digestive abilities of the chicks do not seem to be greatly affected by high ambient temperatures neither with respect to amino acids (Zuprizal et al.

* Present address: Universidade Federal Santa Catarina, 88040-900 Florianopolis, Brasil. 
1993) nor metabolizable energy (ME) value (Geraert et al. 1992). Some authors even suggest that ME can be higher under hot climatic conditions (Keshavarz \& Fuller, 1980). Moreover, enhanced metabolic heat production (extra heat production) per $\mathrm{kJ}$ energy ingested has been reported (MacLeod, 1992; Geraert et al. 1994) which could explain the lower growth for a given intake at high temperatures. However, under hot environmental conditions the reduction in BMR and the decrease in physical activity should reduce the total amount of heat produced. The mechanisms involved in this extra heat production have yet to be identified. Moreover, chickens exposed to heat are often fatter (Chwalibog \& Eggum, 1989; Aïn Baziz et al. 1993), which is indicative of a reduced metabolic rate. Finally, genetically lean broilers appeared to be more resistant to hot conditions, showing enhanced weight gains and better feed and protein efficiencies than their fat-line counterparts despite the fact that the lean birds showed a higher heat increment and increased feathering (Geraert $e t$ al. 1993a).

Elucidating these discrepancies would help to determine nutritional requirements of animals under chronic hot conditions and to define a strategy for adapting production protocols.

Thus, the present study was conducted to investigate the direct effect of chronic heat exposure, independent of feed intake, on growth, body composition and energy retention in chickens in relation to age. Preliminary results of some of the present work have been reported (Geraert et al. 1993b). In order to explain the reduction in growth of heat-exposed chickens and particularly the antagonism between enhanced fatness and extra heat production, a second study was conducted to investigate possible changes in metabolic and endocrine variables. Both studies were also conducted with the aim of defining an experimental model for the further investigation of the effects of chronic heat exposure in growing chickens.

\section{MATERIALS AND METHODS \\ Animals and breeding}

Shaver 1-d-old male broiler chicks $(n 200)$ from a local hatchery (Sicamen, Bouloire, France) were brooded in floor pens. They received a complete starter diet (Table 1) ad lib. up to 14 or $28 \mathrm{~d}$ of age. The lighting programme $23 \mathrm{~h} \mathrm{light-1} \mathrm{h} \mathrm{dark} \mathrm{was} \mathrm{maintained} \mathrm{until}$ the end of the experiment. Ambient temperature was decreased linearly from $32^{\circ}$ at $1 \mathrm{~d}$ of age to reach $22^{\circ}$ at 2 weeks of age.

\section{Experimental procedure}

At 2 and 4 weeks of age, fifty-four birds of similar body weight were transferred to individual battery cages in two controlled-environment rooms where ambient temperature was kept constant either at 22 or $32^{\circ}$ while relative humidity was maintained at about $55 \%$. They were equally distributed into three groups: one at $32^{\circ}$ fed ad lib. (32AL), one group of birds reared at $22^{\circ}$ and fed $a d l i b$. (22AL) and the third group maintained at $22^{\circ}$ and pairfed on the feed intake of the heat-exposed group (22PF). Pair-fed chickens received once daily the amount of feed consumed the previous day by the 32AL group. All birds received a complete grower diet (Table 1). Fig. 1 ( $a$ and $b$ ) shows the actual values for food intake. A period of $2 \mathrm{~d}$ appeared necessary for the chicks to adjust to the ambient temperature, irrespective of age.

\section{Measurements}

Daily feed intake was measured at 09.00 hour each morning. Live weights were recorded after an overnight fast (16 hours) at 2, 4 and 6 weeks of age.

At 4 and 6 weeks of age respectively twelve and ten fasted birds per treatment were 
Table 1. Composition of experimental diets ( $g$ per $\mathrm{kg}$ )

\begin{tabular}{|c|c|c|}
\hline $\begin{array}{l}\text { Diet... } \\
\text { Fed at... }\end{array}$ & $\begin{array}{c}\text { Starter } \\
0-2 \text { weeks }\end{array}$ & $\begin{array}{c}\text { Grower } \\
2-6 \text { weeks }\end{array}$ \\
\hline \multicolumn{3}{|l|}{ Ingredients } \\
\hline Ground yellow maize & 300 & 628 \\
\hline Ground wheat & 300 & - \\
\hline Soyabean meal $(480 \mathrm{~g} \mathrm{CP} / \mathrm{kg})$ & 280 & 279 \\
\hline Maize-gluten meal $(600 \mathrm{~g} \mathrm{CP} / \mathrm{kg})$ & - & $17 \cdot 3$ \\
\hline Rapeseed oil & - & 38 \\
\hline Meat meal ( $550 \mathrm{~g} \mathrm{CP} / \mathrm{kg})$ & 50 & - \\
\hline Animal fat & 41 & - \\
\hline Lysine hydrochloride & - & 0.3 \\
\hline DL-Methionine & $1 \cdot 5$ & $0 \cdot 4$ \\
\hline Calcium carbonate & 6 & $8 \cdot 2$ \\
\hline Dicalcium phosphate & 12 & $19 \cdot \overline{8}$ \\
\hline Sodium chloride & $3 \cdot 5$ & $3 \cdot 0$ \\
\hline Trace minerals* & 1 & 1 \\
\hline Vitamins $\uparrow$ & 5 & 5 \\
\hline \multicolumn{3}{|l|}{ Calculated analysis } \\
\hline $\mathrm{AME}(\mathrm{MJ} / \mathrm{kg})$ & $12 \cdot 71$ & $12 \cdot 96$ \\
\hline Protein & 221 & 205 \\
\hline Lysine & $11 \cdot 6$ & $10 \cdot 5$ \\
\hline$S$ amino acids & $8 \cdot 6$ & $7 \cdot 5$ \\
\hline
\end{tabular}

$\mathrm{CP}$, crude protein $(\mathrm{N} \times 6 \cdot 25)$; AME, apparent metabolizable energy.

${ }^{*}$ Contained (mg/kg diet): $\mathrm{MnO}_{2} 70, \mathrm{ZnO} 50, \mathrm{FeSO}_{4} \cdot 7 \mathrm{H}_{2} \mathrm{O} 70, \mathrm{CuSO}_{4} .5 \mathrm{H}_{2} \mathrm{O} 60, \mathrm{CoCO}_{3} 0 \cdot 3, \mathrm{KI} 1 \cdot 1, \mathrm{CaCO}_{3}$ 803.

$\dagger$ Contained (mg/kg diet): retinol 3.6, cholecalciferol $50 \mu \mathrm{g}$, DL- $\alpha$-tocopheryl acetate 25 , menadione 1, thiamin 1 , riboflavin 4, calcium pantothenate 8 , niacin 15 , pyridoxine 1 , choline chloride 190.

slaughtered after intravenous injection of sodium pentobarbital. Feather weight was determined as the difference of body weight before and after manual plucking. The unfeathered carcases were ground to produce a homogeneous mince and stored at $-20^{\circ}$ until analysis. Minced carcases were freeze-dried and samples were analysed for dry matter, ash, fat and N. Dry matter was determined by oven-drying for $4 \mathrm{~h}$ at $103^{\circ}$, ash by complete combustion $\left(550^{\circ}\right.$ for $\left.24 \mathrm{~h}\right)$ and fat by Soxhlet extraction with diethyl ether. Protein contents of carcases and diets were measured by the macro-Kjeldahl method $(\mathbf{N} \times 6 \cdot 25)$. All data were individually expressed as proportion of live body weight.

To avoid the possible effect of an overnight fast at 4 and 6 weeks of age, birds were allowed to feed again for 1 week with the same procedure as described previously. Fed 5and 7-week-old birds were then slaughtered and their livers were immediately removed, weighed and frozen $\left(-20^{\circ}\right)$ until required for further enzymic analyses.

Protein and lipid gains were calculated between 4 and 6 weeks of age. Energy retention calculations were based on $23.7 \mathrm{~kJ} / \mathrm{g}$ protein and $39 \cdot 2 \mathrm{~kJ} / \mathrm{g}$ lipid retained (Znaniecka, 1967). Heat production was the difference between ME intake (MEI) and total retained energy (RE).

\section{Statistical analysis}

Results are presented as means with their standard errors. Standard errors often differed between the three groups indicating that feed restriction reduced variability while high ambient temperature enhanced heterogeneity, particularly for quantities linked to feed intake: weight gain, final live body weight, feed: gain ratio and chemical body composition. Due to the heterogeneity of variance between treatments (determined by Bartlett's test), 


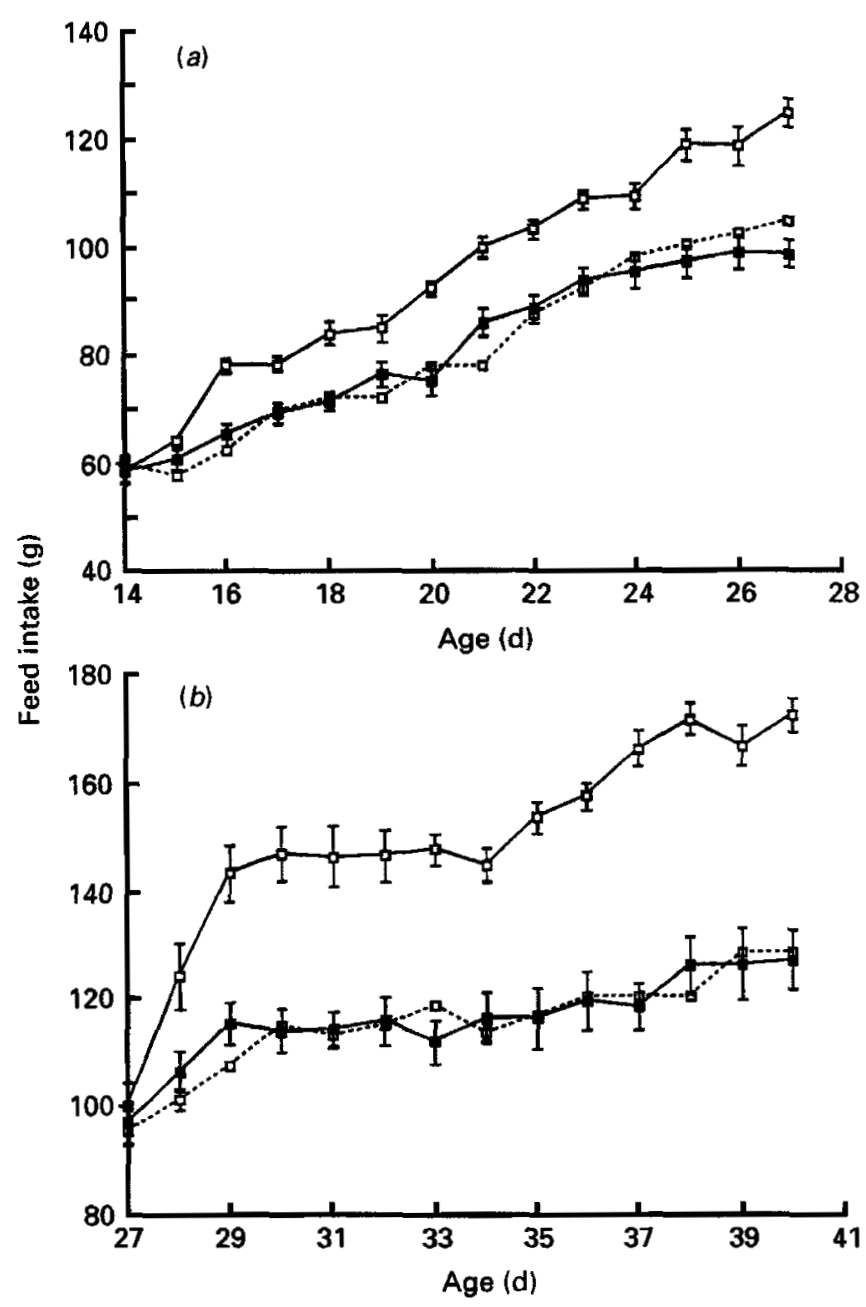

Fig. 1. Effect of chronic heat exposure on daily feed intake (a) between 2 and 4 weeks of age and (b) 4-6 weeks of age and survey of the pair-feeding procedure. ( $-\square)$, ad lib.-fed heat-exposed; ( $\square-\square)$, ad lib.-fed controlexposed; ( $\square--\square$ ), pair-fed control-exposed; for details of diets and procedures, see Table 1 and pp. 196-197. Values are means with their standard errors, represented by vertical bars, for eighteen chickens per treatment.

data were analysed using Kruskal-Wallis's non-parametric test and means were compared by the Mann-Whitney U test. All analyses were performed using Systat software (Systat Inc., Evanston, Il., USA).

\section{RESULTS \\ Growth performance}

Average values for feed intake, weight gain and final body weight are presented in Table 2 . The decrease in feed intake due to heat exposure reached $14 \%$ between 2 and 4 weeks of age, and $24 \%$ between 4 and 6 weeks of age. Weight gain was significantly reduced by feed restriction; -13 and $-24 \%$ between $2-4$ and $4-6$ weeks respectively $(P<0.001)$. At the same feed intake (22PF and $32 \mathrm{AL}$ ), weight gain of chicks was reduced by $5.5 \%$ from 2 to 4 weeks of age, and by $22 \%$ from 4 to 6 weeks of age under hot conditions. Chronic 
Table 2. Average feed intake, body-weight gain and feed conversion of ad lib.-fed heatexposed $(32 A L)$, ad lib.-fed control-exposed $(22 A L)$ and pair-fed control-exposed (22PF) male chickens from 2 to 6 weeks of age*

(Means with their standard errors for eighteen chickens per treatment)

\begin{tabular}{|c|c|c|c|c|c|c|c|}
\hline \multirow[t]{2}{*}{ Treatment... } & \multicolumn{2}{|c|}{$22 \mathrm{AL}$} & \multicolumn{2}{|c|}{$22 \mathrm{PF}$} & \multicolumn{2}{|c|}{$32 \mathrm{AL}$} & \multirow{2}{*}{$\begin{array}{c}\text { Statistical } \\
\text { significance } \\
\text { of difference } \\
P\end{array}$} \\
\hline & Mean & $\mathrm{SE}$ & Mean & $\mathrm{SE}$ & Mean & $\mathbf{S E}$ & \\
\hline \multicolumn{8}{|l|}{ Period $2-4$ weeks of age } \\
\hline Feed intake* $(\mathrm{g} / \mathrm{d})$ & $94 \cdot 3^{a}$ & $1 \cdot 42$ & $80.9^{b}$ & 0.62 & $80 \cdot 9^{b}$ & 2.04 & $<0.001$ \\
\hline $\mathrm{Wt}$ gain $(\mathrm{g})$ & $705^{a}$ & $13 \cdot 4$ & $614^{\mathrm{b}}$ & $6 \cdot 5$ & $580^{\mathrm{b}}$ & $17 \cdot 2$ & $<0.001$ \\
\hline Body wt at 4 weeks (g) & $976^{a}$ & $13 \cdot 9$ & $886^{b}$ & $8 \cdot 4$ & $851^{\mathrm{b}}$ & 17.6 & $<0.001$ \\
\hline Feed:gain ratio $(\mathrm{g} / \mathrm{g})$ & $1.92^{\mathrm{a}}$ & $0 \cdot 02$ & $1.97^{a}$ & 0.02 & $1.97^{\mathrm{a}}$ & 0.04 & 0.441 \\
\hline \multicolumn{8}{|l|}{ Period 4-6 weeks of age } \\
\hline Feed intake $\dagger(\mathrm{g} / \mathrm{d})$ & $154 \cdot 9^{\mathrm{a}}$ & $4 \cdot 17$ & $117 \cdot 4^{b}$ & $2 \cdot 68$ & $118 \cdot 3^{\mathrm{b}}$ & $5 \cdot 4$ & $<0.001$ \\
\hline Wt gain $(\mathrm{g})$ & $1115^{\mathrm{a}}$ & $31 \cdot 7$ & $845^{\mathrm{b}}$ & $14 \cdot 3$ & $659^{\mathrm{c}}$ & $42 \cdot 2$ & $<0.001$ \\
\hline Body wt at 6 weeks (g) & $2041^{\mathrm{a}}$ & $31 \cdot 4$ & $1773^{b}$ & $15 \cdot 5$ & $1584^{\mathrm{c}}$ & $40 \cdot 7$ & $<0-001$ \\
\hline Feed: gain ratio $(\mathrm{g} / \mathrm{g})$ & $2 \cdot 06^{a}$ & 0.03 & $2 \cdot 19^{a}$ & 0.03 & $2 \cdot 85^{\mathrm{b}}$ & 0.20 & $<0.001$ \\
\hline
\end{tabular}

a,b.e Mean values in the same horizontal row with different superscript letters were significantly different $(P<0.05)$.

* For details of diets and procedures, see Table 1 and pp. 196-197.

$\dagger$ Average feed intake was calculated omitting the last day of the experiment due to fasting procedure for weighing the birds.

heat exposure reduced significantly 4 - and 6 -week body weights; -13 and $-22 \%$ respectively. The reduction in body-weight gain was proportional to feed intake in $2-4$ week groups resulting in the absence of a large effect of heat exposure on feed efficiency. Conversely, between 4 and 6 weeks of age, hot environmental conditions significantly increased the average feed: gain ratio; 2.85 for the $32 \mathrm{AL}$ group compared with 2.06 for the 22AL group $(P<0 \cdot 001)$.

\section{Body composition}

Final body composition was affected significantly by heat exposure but not by feed restriction. After 2 weeks of heat exposure feathering expressed as $\mathbf{g}$ feathers was reduced significantly, but when feathering was expressed as a proportion of body weight, no significant difference between groups was found (Table 3 ).

Chemical body composition data indicated an increase in dry matter content of unfeathered carcases in heat-exposed chickens. A significant decrease in body protein content was exhibited in the $32 \mathrm{AL}$ group; $151 \mathrm{v} .163 \mathrm{~g}$ protein $/ \mathrm{kg}$ body weight in $22 \mathrm{AL}$ chickens $(P<0.001)$. Feed restriction did not modify protein content. Lipid deposition was enhanced in heat-exposed (32AL) chickens, particularly when compared with the 22PF group. Heat exposure as well as feed restriction had no effect on body ash content.

The results presented in Table 4 indicated a significant reduction of wet liver weight due to direct or indirect (high temperature) feed restriction, irrespective of the age. When expressed on a live-body-weight basis, the proportional liver weight did not differ between treatments in 5 -week-old birds, but appeared to be smaller $(P=0.01)$ and associated with reduced feed intake in 7-week-old chickens. However, ambient temperature had no effect on liver weight as proportion of body weight for a given feed intake. 
Table 3. Average body composition of ad lib.-fed heat-exposed $(32 A L)$, ad lib.-fed controlexposed (22AL) and pair-fed control-exposed (22PF) male chickens at 6 weeks of age*

(Means with their standard errors for ten chickens per treatment for the experimental period and twelve chickens for the initial body composition)

\begin{tabular}{|c|c|c|c|c|c|c|c|c|c|}
\hline \multirow[t]{3}{*}{ Treatment ... } & \multirow{2}{*}{\multicolumn{2}{|c|}{$\begin{array}{c}\text { Initial } \\
\text { (4 weeks } \\
\text { of age) }\end{array}$}} & \multicolumn{6}{|c|}{ Experimental } & \multirow{3}{*}{$\begin{array}{c}\text { Statistical } \\
\text { significance } \\
\text { of } \\
\text { difference: } \\
P\end{array}$} \\
\hline & & & \multicolumn{2}{|c|}{$22 \mathrm{AL}$} & \multicolumn{2}{|c|}{$22 \mathrm{PF}$} & \multicolumn{2}{|c|}{$32 \mathrm{AL}$} & \\
\hline & Mean & SE & Mean & $\mathbf{S E}$ & Mean & $\mathrm{SE}$ & Mean & $\mathrm{SE}$ & \\
\hline Body wt (BW; g) & 927 & $12 \cdot 5$ & $2028^{\mathrm{a}}$ & $56 \cdot 9$ & $1764^{b}$ & $27 \cdot 8$ & $1570^{\mathrm{e}}$ & 81.4 & $<0.001$ \\
\hline Feather $(\mathrm{g})$ & 46 & $1 \cdot 9$ & $120^{\mathrm{a}}$ & $4 \cdot 3$ & $112^{\mathrm{a}}$ & $8 \cdot 8$ & $87^{\mathrm{b}}$ & 6.9 & $<0.001$ \\
\hline \multicolumn{10}{|c|}{ Body composition (g/kg BW) } \\
\hline Feather & 50 & $2 \cdot 1$ & 59 & 1.9 & 63 & $4 \cdot 5$ & 56 & $5 \cdot 3$ & 0.496 \\
\hline Dry matter & 353 & $4 \cdot 3$ & $369^{\mathrm{a}}$ & $3 \cdot 4$ & $355^{a}$ & 3.6 & $392^{\mathrm{b}}$ & $10 \cdot 8$ & 0.001 \\
\hline Ash & 29 & 0.9 & 27 & 1.0 & 28 & 0.5 & 27 & $1 \cdot 1$ & 0.742 \\
\hline Protein $(\mathrm{N} \times 6.25)$ & 167 & $1 \cdot 4$ & $164^{\mathrm{a}}$ & $1 \cdot 6$ & $162^{\mathrm{a}}$ & 0.9 & $151^{\mathrm{b}}$ & 2.6 & $<0.001$ \\
\hline Lipid & 148 & $5 \cdot 1$ & $172^{\mathrm{a}}$ & $4 \cdot 2$ & $155^{a}$ & 3.9 & $207^{\mathrm{b}}$ & $12 \cdot 0$ & $<0.001$ \\
\hline
\end{tabular}

u,b.e Mean values in the same horizontal row with different superscript letters were significantly different $(P<0-05)$.

* For details of diets and procedures, see Table 1 and pp. 196-197.

Table 4. Average liver weights of ad lib-fed heat-exposed (32AL), ad lib.-fed control-exposed $(22 A L)$ and pair-fed control-exposed $(22 P F)$ male chickens at 5 and 7 weeks of age*

(Means with their standard errors for eight chickens per treatment)

\begin{tabular}{|c|c|c|c|c|c|c|c|}
\hline \multirow[t]{2}{*}{ Treatment... } & \multicolumn{2}{|c|}{$22 \mathrm{AL}$} & \multicolumn{2}{|c|}{$22 \mathrm{PF}$} & \multicolumn{2}{|c|}{$32 \mathrm{AL}$} & \multirow{2}{*}{$\begin{array}{c}\text { Statistical } \\
\text { significance } \\
\text { of difference: } \\
P\end{array}$} \\
\hline & Mean & SE & Mean & SE & Mean & $\mathrm{SE}$ & \\
\hline \multicolumn{8}{|l|}{5 weeks of age } \\
\hline $\begin{array}{l}\text { Body wt (BW; g) } \\
\text { Liver wt: }\end{array}$ & $1391^{\mathrm{a}}$ & $19 \cdot 2$ & $1222^{\mathrm{b}}$ & $14 \cdot 5$ & $1120^{\mathrm{c}}$ & $16 \cdot 7$ & $<0.001$ \\
\hline $\begin{array}{l}\mathrm{g} \\
\mathrm{g} / \mathrm{kg} \mathrm{BW}\end{array}$ & $\begin{array}{l}41 \cdot 8^{\mathrm{a}} \\
30 \cdot 1\end{array}$ & $\begin{array}{l}0.81 \\
0.6\end{array}$ & $\begin{array}{l}34 \cdot 8^{b} \\
28 \cdot 5\end{array}$ & $\begin{array}{l}0.91 \\
0 \cdot 7\end{array}$ & $\begin{array}{l}35 \cdot 2^{b} \\
31 \cdot 4\end{array}$ & $\begin{array}{l}3 \cdot 58 \\
2 \cdot 9\end{array}$ & $\begin{array}{l}0.02 \\
0.42\end{array}$ \\
\hline 7 weeks of age & & & & & & & \\
\hline $\begin{array}{l}\text { BW }(g) \\
\text { Liver wt: }\end{array}$ & $2865^{\mathfrak{a}}$ & $32 \cdot 4$ & $2480^{b}$ & $36 \cdot 4$ & $2033^{c}$ & $42 \cdot 8$ & $<0.001$ \\
\hline $\mathrm{g}$ & $76 \cdot 4^{4}$ & 3.65 & $55 \cdot 6^{b}$ & 1.67 & $47 \cdot 0^{\mathrm{b}}$ & $2 \cdot 41$ & $<0.001$ \\
\hline $\mathrm{g} / \mathrm{kg} \mathrm{BW}$ & $26 \cdot 7^{\natural}$ & $1 \cdot 2$ & $22 \cdot 5^{\mathrm{b}}$ & 0.8 & $23 \cdot 1^{\mathrm{b}}$ & $1 \cdot 0$ & 0.012 \\
\hline
\end{tabular}

a, b,e Mean values in the same horizontal row with different superscript letters were significantly different $(P<0.05)$.

* For details of diets and procedures, see Table 1 and pp. 196-197.

\section{Energy and nitrogen balances}

Protein gain was significantly reduced by feed restriction $(-26 \%)$ and heat exposure $(-54 \%)$. The effect of heat independent of feed intake remained highly significant, $-38 \%$ for ad lib.-fed birds at $22 \mathrm{v} .32^{\circ}$ (Table 5). Protein retention efficiency was only decreased in heat-exposed (32AL) chickens, 0.210 compared with $0.388 \mathrm{~g}$ protein retained $/ \mathrm{g}$ protein ingested in $22 \mathrm{AL}$ birds $(P<0.001)$. This led to a highly significant reduction in the amount of energy retained as protein, $21 \%$ compared with $34 \%$ in birds at thermoneutrality. 
Table 5. Average protein, lipid and energy retentions in ad lib.-fed heat-exposed ( $32 A L)$, ad lib.-fed control-exposed (22AL) and pair-fed control-exposed (22PF) male chickens between 4 and 6 weeks of age*

(Means with their standard errors for ten chickens per treatment)

\begin{tabular}{|c|c|c|c|c|c|c|c|}
\hline \multirow[t]{2}{*}{ Treatment... } & \multicolumn{2}{|c|}{$22 \mathrm{AL}$} & \multicolumn{2}{|c|}{$22 \mathrm{PF}$} & \multicolumn{2}{|c|}{$32 \mathrm{AL}$} & \multirow{2}{*}{$\begin{array}{c}\text { Statistical } \\
\text { significance } \\
\text { of difference } \\
P\end{array}$} \\
\hline & Mean & $\mathrm{SE}$ & Mean & SE & Mean & $\mathrm{SE}$ & \\
\hline Protein gain $(\mathrm{g})$ & $179^{\mathrm{a}}$ & $8 \cdot 6$ & $133^{\mathrm{b}}$ & 4.5 & $83^{c}$ & $14 \cdot 7$ & $<0.001$ \\
\hline Lipid gain (g) & $214^{\mathrm{a}}$ & $16 \cdot 3$ & $138^{b}$ & $8 \cdot 2$ & $185^{a b}$ & $17 \cdot 3$ & 0.002 \\
\hline Protein efficiency $(g / g)$ & $0.388^{2}$ & 0.012 & $0 \cdot 352^{\mathrm{a}}$ & 0.011 & $0 \cdot 210^{\mathrm{b}}$ & 0.034 & $<0.001$ \\
\hline Retained energy (RE; MJ) & $12 \cdot 63^{a}$ & 0.80 & $8 \cdot 57^{\mathrm{b}}$ & 0.39 & $9 \cdot 20^{\mathrm{b}}$ & $0 \cdot 84$ & $<0.001$ \\
\hline Heat production (MJ) & 16.47 & 0.62 & $15 \cdot 28$ & 0.35 & $14-95$ & $0 \cdot 37$ & 0.082 \\
\hline Energy efficiency (MJ/MJ) & $0.432^{\mathrm{a}}$ & $0-016$ & $0 \cdot 359^{\mathrm{b}}$ & 0.015 & $0-376^{\mathrm{ab}}$ & 0.025 & 0.021 \\
\hline $\mathrm{RE}$ as protein (REP; MJ) & $4 \cdot 24^{\mathrm{a}}$ & $0 \cdot 20$ & $3 \cdot 16^{\mathrm{b}}$ & 0.11 & $1 \cdot 96^{c}$ & 0.35 & $<0.001$ \\
\hline $\mathrm{RE}$ as protein (\% RE) & $0.340^{\mathrm{a}}$ & 0.012 & $0.372^{\mathrm{a}}$ & 0.012 & $0.207^{\mathrm{b}}$ & 0.032 & $<0.001$ \\
\hline $\mathrm{RE}$ as fat (REF; MJ) & $8 \cdot 39^{a}$ & 0.64 & $5 \cdot 41^{\mathrm{b}}$ & 0.32 & $7 \cdot 24^{\mathrm{ab}}$ & 0.68 & 0.002 \\
\hline $\mathrm{RE}$ as fat (\% RE) & $0.660^{a}$ & $0 \cdot 012$ & $0.628^{2}$ & 0.012 & $0 \cdot 793^{\mathrm{b}}$ & 0.032 & $<0.001$ \\
\hline $\mathrm{REP} / \mathrm{REF}(\mathrm{MJ} / \mathrm{MJ})$ & $0.519^{a}$ & 0.028 & $0.598^{\mathrm{a}}$ & 0.032 & $0 \cdot 277^{\mathrm{b}}$ & 0.056 & $<0.001$ \\
\hline
\end{tabular}

a,b.e Mean values in the same horizontal row with different superscript letters were significantly different $(P<0.05)$.

* For details of diets and procedures, see Table 1 and pp. 196-197.

On the other hand, heat-exposed (32AL) birds showed enhanced lipid gain compared with the 22PF group, $185 \mathrm{~g}$ compared with $138 \mathrm{~g}(P=0.07)$. The percentage of energy retained as body lipid was 79 in the $32 \mathrm{AL}$ group and approximately 64 in the $22^{\circ}$ groups. Feed restriction alone reduced lipid deposition to a greater extent than that of protein deposition, $-36 \%$ compared with $-26 \%$.

Total heat production and RE were reduced by direct or indirect feed restriction. However, energy efficiency was decreased in $22 \mathrm{PF}$ group compared with the 22AL group, while the heat-exposed group showed a non-significant reduction in its energy efficiency compared with both $22^{\circ}$ groups. The ratio between RE as protein and RE as fat showed a large reduction with heat exposure, 0.28 compared with 0.56 in the $22^{\circ}$ groups $(P<0.001)$.

\section{DISCUSSION}

The control temperature chosen in the study $\left(22^{\circ}\right)$, while thermoneutral at 4 weeks of age, could appear low for 14-d-old chicks and, thus, might have enhanced feed intake and increased the relative effect of high temperature. However, the ambient temperature of $32^{\circ}$ had a more depressive effect on feed intake and growth of 4-6-week-old chickens than before 4 weeks of age. The mean reduction in feed intake was slightly lower for the 2-4-week period and largely higher for the 4-6-week periods than the range of values for feed intake reported in the review by Austic (1985), for the total growing period, showing the effect of age on sensitivity to heat exposure. The results also reveal that about half the growth reduction effect of chronic heat exposure was not related to feed intake (Dale \& Fuller, 1980) and, thus, would have other origins. Improving feed intake by dietary fat supplementation (Dale \& Fuller, 1979) or by force-feeding techniques up to $16 \%$ above $a d$ lib. feed intake (Smith \& Teeter, 1987) increased weight gain and part yields but was accompanied by enhanced fatness. Mammals seem to react differently to the same range of variation of the ambient temperature. Growing piglets $(10-30 \mathrm{~kg})$ reduced their growth by 
$16 \%$ at $31.5^{\circ}$ compared with $18.5^{\circ}$ (Rinaldo \& Le Dividich, 1991), while Christon et al. (1984) observed only a slight decrease $(-5 \%)$ in growth rate of male rats exposed at $31^{\circ}$ compared with $21^{\circ}$. However, both authors reported a significant improvement in feed efficiency under their hot environmental conditions, indicating a greater decrease in feed intake than in growth unlike the pattern for growing chickens (Meltzer, 1986).

The insulating properties of feathers might be detrimental under hot conditions. Unlike a previous experiment with genetically-lean and -fat chickens exposed to $32^{\circ}$ from 1 - $d$-old to 9 weeks of age (Greraert et al. 1993a), heat exposure for 2 weeks has not been sufficient to reduce feathering significantly in the heat-exposed chicks. Moreover, metabolic heat production might be enhanced through an increase in energy expenditure associated with respiratory muscular activity due to panting (Brackenbury \& Avery, 1980) and through an increase in diet-induced thermogenesis (MacLeod, 1992; Geraert et al. 1994). In the present study the increase in heat production as a percentage of MEI reached about 10 . The excess energy ingested compared with the heat dissipation capacity under hot conditions may then be deposited as body lipids, which might explain the observed excessive fatness in chickens exposed to warm environments. Any physical means of increasing heat-loss mechanisms such as a high ventilation rate, a low relative humidity or a circadian rhythm of ambient temperature could limit the amount of fat deposited, which might explain discrepancies observed in published results on fatness under heat exposure (Howlider \& Rose, 1987; Keshavarz \& Fuller, 1980). Moreover, enhancing heat losses by genetic reduction of feathering (naked-neck genotype) leads to increased growth performance and decreased fat deposition (Cahaner et al. 1993).

While genetically-lean chickens exhibited a greater proportion of feather under hot conditions and enhanced heat production as a percentage of MEI than their fat counterparts (Geraert et al. 1993a), they showed enhanced growth and lowered lipid deposition. Leenstra \& Cahaner (1992) and Cahaner \& Leenstra (1992) also reported that broilers selected for improved feed conversion (FC line) showed the best growth rate and the lowest body fat content under a hot climate. Lean and FC genotypes are characterized by a lower energetic efficiency (i.e. an increased heat production per $\mathrm{MJ}$ ingested) which might signify improved heat loss capacities. When given an excess of protein under hot environmental conditions, lean genotypes demonstrated a greater increase in fat deposition relative to the control temperature than fat chickens (Geraert et al. 1993a). Such results indicate the difficulties birds have in getting rid of the extra heat induced by enhanced dietary protein supply and could explain the greater amount of fat deposited.

The energetic efficiency data revealed an absence of difference between ad lib.-fed birds exposed at $32 v .22^{\circ}$. Energetic efficiency was reduced by the extra heat production but enhanced by the increased fatness. These adverse effects would result in a similar energetic efficiency for control and heat-exposed ad lib.-fed birds, although this is slightly decreased under hot conditions. In growing pigs, Rinaldo \& Le Dividich (1991) did not report an effect of hot conditions $\left(31.5^{\circ}\right)$ on the partition of energy retained between protein and lipids when data were adjusted for the same MEI or the same RE. Lipid storage even decreased under hot conditions and ad lib. feeding; 355 v. $246 \mathrm{~kJ} / \mathrm{kg}$ body weight ${ }^{0.75}$ per d at 18.5 and $31.5^{\circ}$ respectively.

Using growing chickens between 21 and 42 d of age, Chwalibog \& Eggum (1989) did not find an effect of ambient temperature on protein content in the range $15-40^{\circ}$ but they did observe enhanced fat content. In the present experiment, heat-exposed chickens showed a significant decrease in body protein content, protein gain and protein retained:protein intake. Such results would suggest a change in protein metabolism, a decrease in protein synthesis or an increase in catabolic rate. This has yet to be studied further. Moreover, the reduction in the absolute feather weight of heat-exposed birds would result in less $\mathrm{S}$ amino 
acids diverted towards feather protein synthesis. The consequence might be an imbalance in amino acids remaining in the circulation leading to an excess of some amino acids, which could reduce the efficiency of protein synthesis. Chronic heat exposure might also increase the amount of amino acid $\mathrm{C}$ chains diverted towards lipogenesis to avoid any increase in heat produced through total oxidation. The fact that restricted-fed chickens were able to retain as much body protein as ad lib.-fed birds as a proportion of body weight, and have similar feather protein accretion, suggests a specific effect of the environmental temperature on protein metabolism of the chicks. Feed restriction did not reduce absolute feather weight which means that feathering, and particularly feather protein deposition, takes over body protein accretion when amino acid supply is limited. Such predominance has been reported also when restriction of the amino acid supply is imposed in chicks (Leclercq et al. 1993).

Unlike data reported on growing rats (Christon et al. 1984), the amount of mineral deposited in the chickens was not affected by temperature or feeding treatment and suggests the absence of major skeletal changes under chronic heat exposure. Birds would have sufficient intake of minerals for their skeleton growth requirements when their feed intake was greatly depressed.

Because of its great importance as a metabolic site, liver characteristics were recorded. Unlike genetically-lean and -fat chickens (Saadoun \& Leclercq, 1987) where fat genotypes demonstrated an enhanced hepatic lipogenesis, the enhanced fatness observed in heatexposed birds was not associated with an increase in liver weight on an absolute or liveweight basis. Balnave (1972) also reported a decrease in liver size in heat-exposed birds $\left(30 v .17^{\circ}\right)$ and found reduced specific activity of malic enzyme (EC. 1.1.1.38). Further investigations on lipid metabolism should be undertaken. The increased fat deposition at the abdominal and subcutaneous sites, as reported recently (Aïn Baziz et al. 1993), could result not only from an enhanced lipogenesis but also from a decreased lipid mobilization or enhanced peripheral uptake through lipoprotein lipase (EC 3.1.1.34) activity.

Chronic heat exposure appears to have an effect on growth, body composition and energy retention independent of the decrease in feed intake. The reduced growth and protein deposition would suggest changes in energy and protein nutrient utilization which have to be further investigated.

The work was supported by a grant from CNPq (Brasilia, Brasil). The authors gratefully acknowledge K. Gerard for his technical assistance in breeding the chickens.

\section{REFERENCES}

Aïn Baziz, H., Geraert, P. A. \& Guillaumin, S. (1990). Effects of high temperature and dietary composition on growth, body composition and energy retention in broilers. Proceedings of the VIIIth European Poultry Conference, vol. 1; pp. 626-629. Fira de Barcelona: World's Poultry Science Association Spanish Branch.

Aïn Baziz, H., Geraert, P. A., Padilha, J. C. F., Guillaumin, S., Marché, G. \& Ricard, F. H. (1993). Does heat exposure modify carcass quality of broilers? In Proceedings of the XIth European Symposium on the Quality of Poultry Meat, vol. 1, pp. 52-58 [P. Colin, J. Culioli and F. H. Ricard, editors]. Tours; France: World's Poultry Science Association, French Branch.

Austic, R. E. (1985). Feeding poultry in hot and cold climates. In Stress Physiology in Livestock, vol. 3, pp. 123-136 [M. K. Yousef, editor]. Boca Raton: CRC Press.

Balnave, D. (1972). The effect of temperature and length of exposure on liver composition and hepatic lipogenic enzyme activity in the immature male chick (Gallus domesticus). Comparative Biochemistry and Physiology 43B, $999-1007$

Brackenbury, J. H. \& Avery, P. (1980). Energy consumption and ventilatory mechanisms in the exercising fowl. Comparative Biochemistry and Physiology 66A, 439-445.

Cahaner, A., Deeb, N. \& Gutman, M. (1993). Effects of the plumage-reducing naked-neck (Na) gene on the performance of fast-growing broilers at normal and high ambient temperatures. Poultry Science 72, 767-775.

Cahaner, A. \& Leenstra, F. (1992). Effects of high temperature on growth and efficiency of male and female broilers from lines selected for high weight gain, favorable feed conversion, and high or low fat content. Poultry Science 72, 1237-1250. 
Christon, R., Le Dividich, J., Seve, B. \& Aumaitre, A. (1984). Influence de la temperature ambiante sur l'utilisation métabolique de l'énergie et de l'azote alimentaires chez le rat en croissance (Effect of ambient temperature on the metabolic use of dietary energy and nitrogen in growing rat). Reproduction, Nutrition, Development 24, 327-341.

Chwalibog, A. \& Eggum, B. O. (1989). Effect of temperature on performance, heat production, evaporative heat loss and body composition in chickens. Archiv für Geflügelkunde 53, 179-184.

Dale, N. M. \& Fuller, H. L. (1979). Effect of diet composition on feed intake and growth of chicks under heat stress. I. Dietary fat levels. Poultry Science 58, 1529-1534.

Dale, N. M. \& Fuller, H. L. (1980). Effect of diet composition on feed intake and growth of chicks under heat stress. II. Constant vs. cycling temperatures. Poultry Science 59, 1434-1441.

Geraert, P. A., Guillaumin, S. \& Zuprizal (1992). Effect of high ambient temperature on dietary ME value in genetically lean and fat chickens. Poultry Science 71, 2113-2116.

Geraert, P. A., Guillaumin, S. \& Leclercq, B. (1993a). Are genetically lean broilers more resistant to hot climate? British Poultry Science 34, 643-653.

Geraert, P. A., Padilha, J. C. F. \& Guillaumin, S. (1993b). Metabolic and endocrine changes induced by heat exposure in chickens. Proceedings of the Nutrition Society 52, 165A.

Geraert, P. A., Padilha, J. C. F., Aïn Baziz, H. \& Guillaumin, S. (1994). Heat-induced changes in energy metabolism in broilers. In Proceedings of the 13th Symposium on Energy Metabolism of Farm Animals. European Association for Animal Production Publication no. 76, pp. 375-378 [J. F. Aguilera, editor]. Madrid: Consejo Superior de Investigaciones Cientificas.

Howlider, M. A. R. \& Rose, S. P. (1987). Temperature and growth in broilers. Worlds Poultry Science Journal 43, 228-237.

Keshavarz, K. \& Fuller, H. L. (1980). The influence of widely fluctuating temperatures on heat production and energetic efficiency of broilers. Poultry Science 59, 2121-2128.

Leclercq, B., Chagneau, A. M., Cochard, T., Hamzaoui, S. \& Larbier, M. (1993). Comparative utilisation of sulphur-containing amino acids by genetically lean or fat chickens. British Poultry Science 34, 383-391.

Leenstra, F. \& Cahaner, A. (1992). Effects of low, normal, and high temperatures on slaughter yield of broilers from lines selected for high weight gain, favorable feed conversion, and high or low fat content. Poultry Science 71, 1994-2006.

MacLeod, M. G. (1992). Energy and nitrogen intake, expenditure and retention at $32^{\circ}$ in growing fowl given diets with a wide range of energy and protein contents. British Journal of Nutrition 67, 195-206.

Meltzer, A. (1986). Efficiency of effect of high ambient temperatures on food utilisation in male broilers. British Poultry Science 27, 349-351.

Rinaldo, D. \& Le Dividich, J. (1991). Effects of warm exposure on adipose tissue and muscle metabolism in growing pigs. Comparative Biochemistry and Physiology 100A, 995-1002.

Saadoun, A. \& Leclercq, B. (1987). In vivo lipogenesis of genetically lean and fat chickens: effects of nutritional state and dietary fat. Journal of Nutrition 117, 428-435.

Smith, M. O. \& Teeter, R. G. (1987). Influence of feed intake and ambient temperature stress on the relative yield of broiler parts. Nutrition Reports International 35, 299-306.

Znaniecka, G. (1967). Calorific value of protein and fat of the chicken's body, In Energy Metabolism of Farm Animals. Proceedings of the 4th European Association for Animal Production Symposium, pp. 407-408 [K. L. Blaxter, J. Kielanowski and G. Thorbek, editors]. Warsaw, Poland: Oriel Press Ltd.

Zuprizal, Larbier, M., Chagneau, A. M. \& Geraert, P. A. (1993). Influence of ambient temperature on true digestibility of protein and amino acids of rapeseed and soybean meals. Poultry Science 72, 289-295. 